\title{
The French School of Violin Playing between Revolution and Reaction: A Comparison of the Treatises of 1803 and 1834 by Pierre Baillot
}

\author{
Douglas Macnicol \\ The Australian National University \\ douglas.macnicol@anu.edu.au
}

\begin{abstract}
Pierre Baillot (1771-1842) was a central figure in the development of the early nineteenth-century French School of violin playing. This school was itself the source of the twentieth-century Russian and American schools, and all the great players of the modern era can trace their lineage back to Baillot and his colleagues. The French School was the first to systematize violin teaching within an institutional framework with normative aspirations. Its history is bound up with that of the Paris Conservatoire, established in 1795. Work by French scholars of the Conservatoire and its teaching has tended to assert a continuity of ideals and aesthetics across time, even an essential Frenchness, and work by English-language scholars has been more concerned with the influence of the School on developments in playing styles and composition than on the evolution of attitudes to music teaching. This analysis of the language of the two founding pedagogical texts reveals a contested cultural landscape, and explores how a revolutionary institution with lofty principles could be overtaken by cultural change in a few short decades. It finishes by questioning the traditional elision of the French and Franco-Belgian schools, and suggests that Brussels, rather than constituting a mere branch of the Paris school, rescued it from premature irrelevance.
\end{abstract}

\section{Introduction}

The French School of violin playing came into being within and at the same time as the Paris Conservatoire of Music, and its success made up much of the early success of the institution which was to serve as template for all the conservatories to follow. ${ }^{1}$ This is partly because of the leading role played by the violin relative to other instruments at the time, and partly because of the work of Pierre Marie François de Sales Baillot (1771-1842) and his fellow violin professors in Paris, notably Pierre Rode (1774-1830) and Rodolphe Kreutzer (1766-1831). All three can be characterized as disciples of Giovanni Battista Viotti (1755-1824), although only Rode was actually his pupil. Their pedagogical work finds its first articulation in

1 See, for example, Laetitia Chassain, 'Le Conservatoire et la notion d'"école française"' and André Lodéon, 'La longue marche des conservatoires', in Le Conservatoire de Paris: deux cents ans de pédagogie, 1795-1995, ed. Anne Bongrain and Alain Poirier (Paris: Buchet/ Chastel, 1999): 15-28 and 403-8. 
the etudes of Kreutzer ${ }^{2}$ and Rode, ${ }^{3}$ and in the official violin method drafted by Baillot in consultation with these two colleagues and published by the Conservatoire in $1803 .{ }^{4}$ The Kreutzer and Rode etudes exploit the possibilities of the new Tourte bow and remain central to the teaching repertoire today, but the 1803 Méthode is generally overlooked in favour of the much more detailed L'Art $d u$ violon, also written by Baillot, and published in $1834 .^{5}$ The 1834 treatise may no longer be much used in actual violin teaching, but it is a central reference for anyone interested in the French School, contemporary performance practice and the genesis of modern violin playing. It covers with great thoroughness all aspects of violin technique and notably of expressive technique. It is, moreover, the work of a very well-read man who has evidently taken his combined vocations as performer, teacher and composer very seriously. In contrast with the nearcontemporaneous method by Louis Spohr, a work of comparable reach albeit in the German and English-speaking realms, ${ }^{6}$ it contains a wealth of thought on what it is to be a musician; and this is what makes it so interesting not only from a musicological point of view, but also from a broader, cultural-historical perspective.

Baillot's considerable importance to the history of the Conservatoire and the history of violin playing derives from three things in addition to his acknowledged prowess as a performer: his skill as a writer, his devotion to teaching, and the length of his tenure at the Conservatoire at this formative juncture. These things came together to produce the treatise of 1834 and a living legacy in the form of many students who became significant musical and pedagogical figures in their own right: Habeneck, Mazas, Sauzay and Dancla, to name just a few. One can thus defend Anne Penesco's eulogistic claim that Baillot 'showed an unfailing devotion to that institution [the Conservatoire] and contributed not only a great part of its international reputation but also of its soul'. ${ }^{7}$

The Conservatoire de Musique was established by decree of the National Convention on 3 August 1795. It was one of a suite of educational institutions voted by the National Convention and established under the Directory, and thus formed part of a long-term project to lay the foundations of a genuinely democratic

2 First published as 40 Études ou Caprices in 1796, later as 42.

324 caprices en formes d'études. Uncertain when these were written, but Clive Brown and Jonathan Schwartz in Grove date them to circa 1815: Clive Brown and Boris Schwartz, 'Rode, (Jacques) Pierre (Joseph)', in Grove Music Online, Oxford Music Online, www.oxfordmusic. com.

4 Pierre Baillot, Méthode de violon par Mm. Baillot, Rode et Kreutzer (Paris, 1803). I shall generally refer to this as the Méthode. The translations are my own. I have retained the spelling of the original French, but have adopted modern spacing in association with punctuation. For Baillot's key role in drafting this document see, for example, Brigitte François-Sappey, 'Pierre Marie François de Sales Baillot (1771-1842) par lui-même: étude du sociologie musicale', Recherches sur la musique française classique 18 (1978): 143.

5 Pierre Baillot, L'Art du violon: nouvelle méthode (Paris, 1834). Again, the translations are my own, but I have also drawn on Louise Goldberg's translation in Pierre Baillot, The Art of the Violin (Evanston: Northwestern University Press, 1991). A further note: some writers such as Louise Goldberg give the date of publication as 1835, but both Grove and Fétis give it as 1834.

6 Louis Spohr, Violinschule (Vienna: Haslinger, 1833; reprint: Munich/Salzburg, 2000).

7 Anne Penesco, 'Pierre Baillot et l'école franco-belge de violon', in Le Conservatoire de Paris: deux cents ans de pédagogie, 1795-1995, ed. Bongrain and Poirier, 91. My translation. 
republic through creating an educated citizenry. ${ }^{8}$ More specifically, its four principal purposes were: (1) to set a standard for instruction which would serve as a model for the whole of the country; (2) to provide music and musicians for the new Revolutionary festivals; (3) to provide France with a school to rival those of Italy and Germany; and (4) to be the arbiter of musical taste for the country. ${ }^{9}$ Key to the standardization of instruction were the 14 official methods published between 1800 and 1814, among which was the Méthode de violon par Mm. Baillot, Rode et Kreutzer, published in 1803 (Fig. 1). Two ideas stand out at this formative moment: the desire for uniformity, and the belief in the existence of fixed principles on which the new school would be founded. In the case of violin instruction, uniformity of approach was aided by the fact that Baillot, Rode and Kreutzer were all disciples of Viotti, whose arrival in Paris in 1782 rapidly established his pre-eminence - a pre-eminence not impaired by his move to London ten years later. It may be a rare case in which a school is set up in emulation of an artist rather than by the master himself. Viotti's playing was famous for its beauty of sound, power and expression as much as for its virtuosity, and the Méthode was written with the clear intent of establishing this style as the model to follow.

The 1803 Méthode is in two parts: Part One is the method itself, which consists of some basic advice concerning posture and how to hold the instrument, followed by a large number of scale exercises to develop good intonation, some advice on ornamentation and a variety of bowing exercises. In drafting the key text sections, Baillot has set himself to the articulation of principles he clearly believes to be immutable. The introduction that precedes Part One has something of the character of a manifesto, particularly when taken together with Part Two, which deals with principles of expression. This section defines key aspects of music such as sound, rhythm, style and taste.

The 1834 Art du violon (Fig. 2) follows the same structure in expanded form. Of principal interest to this comparative analysis are the text sections of both treatises that have to do with ideology rather than strictly practical advice. The key sections are the foreword to 1834 ('Observations relatives à cette nouvelle méthode'), the two versions of the introduction in the two editions, the section titled 'Progrès de l'art' (new to 1834), and the short second part which is the same in both versions, with the exception of three-quarters of a page of introductory remarks to that part in the later version. With only two exceptions, all the text of 1803 finds its way into some part of 1834. Because of all this common ground, the changes in language and emphasis are instructive.

The foreword to L'Art du violon defines it as an update of the original 1803 Méthode, expanded to account for technical progress and the lessons of experience, but conserving the fundamental principles of the original. ${ }^{10}$ This is true as far as it goes, but a closer reading of the two texts reveals changes in language and emphasis that suggest a writer attempting to negotiate shifting cultural currents. These

8 See, for example, James Livesey, Making Democracy in the French Revolution (Cambridge: Harvard University Press, 2001).

9 Cynthia M. Gessele, 'The Conservatoire de Musique and National Music Education in France, 1795-1801', in Music and the French Revolution, ed. Malcolm Boyd (Cambridge University Press, 1992): 191-210, esp. 200. See also Chassain, 'Le Conservatoire', 15. Gessele emphasizes the second and fourth purposes listed and Chassain the first and third.

10 Baillot, L'Art du violon, 2. 


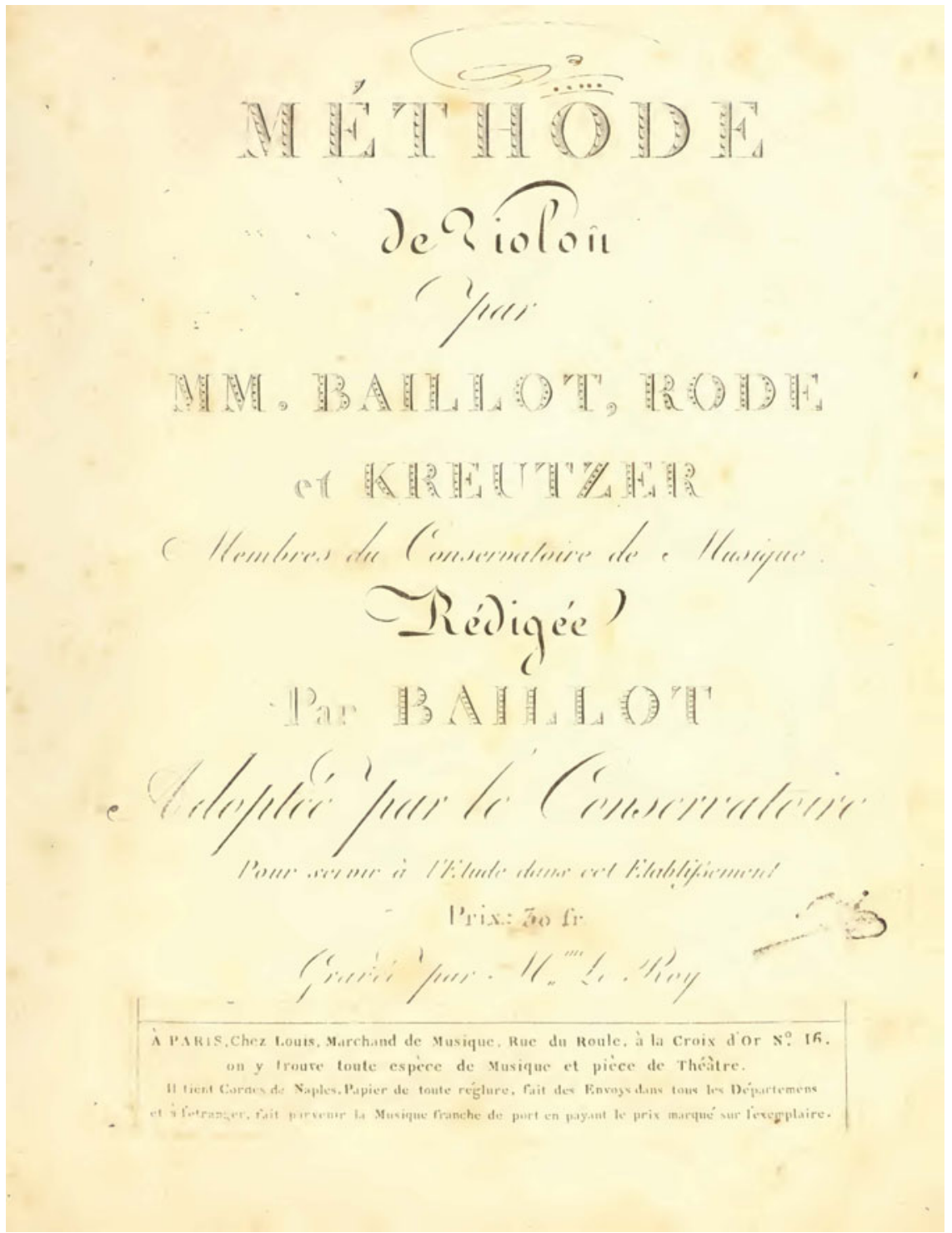

Fig. 1 Cover of the Méthode de violon (1803). All illustrations are excerpted from digital reproductions available via the International Music Score Library Project.

changes, which are the subject of this article, include a much stronger positioning of the School within an historical tradition, a whole new section on 'Progrès de l'art' that betrays signs of unresolved tension between innovation and preservation, hints of a more inward-looking nationalism, and a new appeal to moral judgement. Taken together, they suggest a musical approach struggling to maintain its relevance in the face of cultural challenge.

There is a change in the overall character of the documents which could be ascribed to the ageing of their author: one was written by a young man and the 


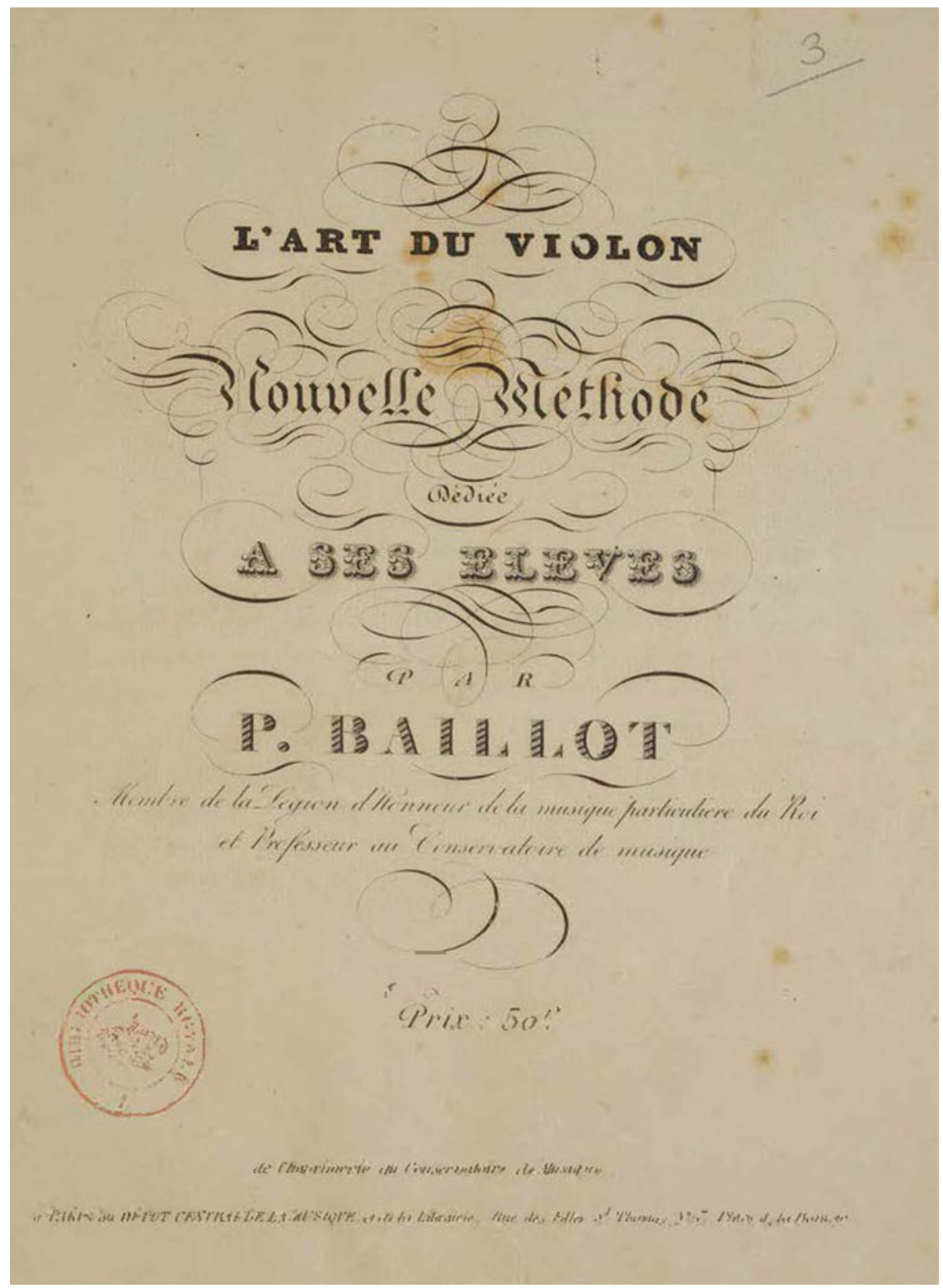

Fig. 2 Cover of L'Art du violon (1834).

other by a man approaching the end of his life. Where one has the character of a manifesto, the other has the character of a testament. Where one is a statement of intent, the other is a statement of achievement. This aspect of early/late style may overlay the points made in this article, but I suggest that it does not contradict them. In 1803, Baillot was 33, Kreutzer was 37 and Rode only 29. The youth of the School coincided with the youth of its main exponents. 


\section{Existing Scholarship}

Previous English-language writing on the French Violin School has been principally concerned with developments in instrument construction, playing technique and both violinistic and compositional style. These aspects have been explored in great detail by writers such as David Boyden, Robin Stowell, Boris Schwartz and Clive Brown. ${ }^{11}$ Chappell White's much quoted study of Viotti ${ }^{12}$ does not concern itself with pedagogy, but it is useful for two things. First, it documents the new seriousness Viotti brought to the genre of the violin concerto, a seriousness matched by that brought by his disciples to the business of teaching, as I shall discuss. Second, in its survey of Viotti's many antecedents, it demonstrates the importance of urban centres capable of sustaining numbers of musicians whose works could provide that spur to 'noble emulation' in Baillot's phrase. ${ }^{13}$ Paris led Viotti to introduce more lyricism and drama into his concerto writing, whereas the London concertos then become more classical again. ${ }^{14}$ The French School would not have developed as it did without the revolutionary - and counterrevolutionary - ferment of the French metropolis.

A recent example of this scholarly tradition, which takes Baillot's 1803 Méthode as its subject, is a 2014 masters thesis by Airdrie Kalyn Robinson. ${ }^{15}$ The aim of the thesis is stated as 'defining the musical characteristics of the French Violin School by identifying these novel features in the Méthode $e^{16}$ While Robinson identifies the under-researched nature of the Méthode, and asserts both its importance and that of $L^{\prime} A r t d u$ violon (to which she oddly gives the date of 1831), she makes only the most cursory comparison of the two and deals with neither the broader educational politics surrounding the Conservatoire's creation nor with its ethos, beyond its concern for standardization. This kind of approach is very strong on what Baillot and his colleagues taught, but does not much address the how or the why. It concerns itself with musical language rather than the language of the pedagogical texts, and it shows little interest in sources such as memoirs, ${ }^{17}$ which are capable

11 For example, David Boyden, The History of Violin Playing from its Origins to 1761 (Oxford: Oxford University Press, 1965); Robin Stowell, Violin Technique and Performance Practice in the Late Eighteenth and Early Nineteenth Centuries (Cambridge: Cambridge University Press, 1985); Boris Schwartz, French Instrumental Music Between the Revolutions (1789-1830) (New York, 1987) and 'Beethoven and the French Violin School', The Music Quarterly 44 (1958): 431-44; Clive Brown, Classical and Romantic Performing Practice 1750 1900 (New York: Oxford University Press, 1999). Boyden and Stowell are particularly strong on instrument developments and playing techniques, Schwartz on compositional styles, and Brown covers all aspects thoroughly.

12 Chappell White, From Vivaldi to Viotti: A History of the Early Classical Violin Concerto (Philadelphia: Gordon and Breach, 1992).

13 'la noble émulation', Baillot, Méthode, 3.

14 White, From Vivaldi to Viotti, 342-4.

15 Airdrie Kalyn Robinson, 'Plein de feu, plein d'audace, plein de change': Examining the Role of the Méthode de violon in the Establishment of the French Violin School (MM thesis, University of Lethbridge, 2014).

${ }^{16}$ Robinson, 'Plein de feu, plein d'audace, plein de change', 4.

17 We have memoirs of former Baillot students such as Charles Dancla and Eugène Sauzay (the latter available only in François-Sappey's edition): Charles Dancla, Notes et Souvenirs (Paris: Delamotte, 1893) and Eugène Sauzay and Brigitte François-Sappey, 'La vie musicale à Paris à travers les Mémoires d'Eugène Sauzay (1809-1901)', Revue de Musicologie 60 (1974): 159-210. Berlioz's memoirs are memorable and revealing on many 
of affording glimpses inside the School, understood not only as a body of musical practice but also as a community of individuals linked together across time.

Bruce Schueneman's The French Violin School ${ }^{18}$ belongs to the tradition of English-language scholarship described above, but forms a part-exception. It focuses principally on the French School as a school of violin writing and on biographical details of its members, but it also devotes a few pages to the language of the Baillot treatises. ${ }^{19}$ However, it makes no comparison between the two and draws some questionable and contradictory conclusions as to the nature of the philosophy presented. For example, it classes the insistence of the School on the singing nature of the violin as romantic, before acknowledging the association with the longstanding dominance of opera, a much more likely cause of the link. ${ }^{20}$ As Vanessa Agnew has noted, vocal music was valued more highly in the eighteenth century than instrumental music everywhere in Europe except Germany, and the rise of instrumental music (to which Baillot and his students contributed) went hand-in-hand with the rise of German music. ${ }^{21}$ Schueneman goes as far as to characterize the 1834 treatise as 'a romantic manifesto which aims to lay the groundwork for a more expressive art' ${ }^{22}$ This is to misread the document, which is rather a testament to a well-established school which already considered itself eminently expressive, and which, as I shall argue, was resisting key romantic currents. It is also questionable to assert that the romantic movement was already 'well underway' in France in $1834 .{ }^{23}$ On the contrary, romanticism was only just making its breakthrough in literature, drama and music in 1830, with the publication of Stendhal's Le rouge et le noir, the tumultuous first performance of Hugo's Hernani, and the first performance of Berlioz's Symphonie Fantastique. Schueneman is on surer ground in characterizing the romantic movement as 'comprised of elements of pure showmanship (like Paganini or Liszt) as well as striving for an inward illumination through art', and noting that the French School rejected empty technical display, ${ }^{24}$ although he fails to note that the preoccupation with teaching which is characteristic of the School, and indeed of the Revolution as a whole, formed a counterbalance to this inwardness.

Much of the relevant work by French scholars was published around 1995, the two-hundredth anniversary of the Conservatoire's foundation, and it tends to have somewhat of a celebratory character, ${ }^{25}$ focusing on the development of the

fronts: Hector Berlioz, Mémoires (Paris: Garnier-Flammarion, 1969) (originally published Paris, 1869).

${ }_{18}$ Bruce Schueneman, The French Violin School: Viotti, Rode, Kreutzer, Baillot, and their Contemporaries, ed. William E Studwell (Kingsville, TX: Lyre of Orpheus Press, 2002).

19 'The Musical Philosophy of the French School', in Schueneman, The French Violin School, 4-7.

${ }^{20}$ Schueneman, The French Violin School, 4-5.

21 See Vanessa Agnew, Enlightenment Orpheus: The Power of Music in Other Worlds

(New York: Oxford University Press, 2008): 6 and 172.

${ }^{22}$ Schueneman, The French Violin School, 6.

${ }^{23}$ French musicologists seem to regard the period 1790-1830 as 'classical' and the period 1830-1870 as 'romantic'. See, for example, the Flammarion series which includes: La Musique en France à l'époque romantique (1830-1870), ed. Elisabeth Bernard and Joseph-Marc Bailbé (Paris: Flammarion, 1991).

${ }^{24}$ Schueneman, The French Violin School, 6.

25 The title of Élizabeth Delafon-Bernard, 'Habeneck et la Société des concerts du Conservatoire: un destin exemplaire' in Le Conservatoire de Paris: Des menus-plaisirs à la cité 
institution in the context of national traditions. ${ }^{26}$ In addition, Baillot's iconic status within the history of French musical life may have inhibited critical examination of his writings on the part of French scholars, ${ }^{27}$ and his intimate association with the history of the Conservatoire has led to an emphasis on continuity rather than contest and change. ${ }^{28}$ Nonetheless, Brigitte François-Sappey's 1978 study of Baillot's life and work through his writings is an essential reference, and Anne Penesco has written extensively on Baillot, his colleagues and the living tradition they began. ${ }^{29}$ More broadly, there is much important French-language work on the history of the Conservatoire from biographical, sociological and cultural history perspectives, often by scholars intimately connected with the current institution. To this we must add Cynthia Gessele's account of the cultural politics leading to the creation of the institution, which shows among other things that the desire for standardization in the field of music education, as in so many other fields, predated the Revolution. ${ }^{30}$

\section{A Military-Style Institution for a Time of Military Strife?}

This article aims to afford insight into the competing discourses surrounding and animating the establishment of the Conservatoire and its pedagogical model. In terms of approach, its most direct comparator is a recent article by Kailan Rubinoff, which seeks to characterize the ethos of the Conservatoire and explain its origins from a Foucauldian perspective, taking the official flute method as its starting point. ${ }^{31}$ Through an analysis of the language used in the method and the kind of pedagogical material presented, together with an examination of the disciplinary regulations of the institution, Rubinoff builds a case that the success of the Conservatoire was based on a new, military style of instruction, a style that was apt for the production of disciplined foot soldiers in the developing symphony orchestra at the expense of more creative and improvisatory aspects of music-making. She traces the origin of this style to Bernard Sarrette's National Guard school, which was first formed in 1792, and became the Institut National de Musique in 1793 before joining with the smaller École de Chant to become

de la musique, 1795-1995, ed. Anne Bongrain (Paris: Buchet-Chastel, 1996): 97-116 is illustrative of this tendency.

${ }^{26}$ See, for example, Laetitia Chassain-Dolliou, Le Conservatoire de Paris, ou les voies de la création (Paris, 1995); Bongrain and Poirier, eds, Le Conservatoire de Paris: deux cents ans de pédagogie; Anne Bongrain ed., Le Conservatoire de Paris: Des menus-plaisirs à la cité de la musique; Emmanuel Hondré, ed, Le Conservatoire de musique de Paris: Regards sur une institution et son histoire (Paris: Gallimard, 1996). I have yet to find a reference in these French sources to Spohr's account of his visit to Paris in 1820, even though it is valuable perspective from a sympathetic outsider. See below under 'Nationalism' and Louis Spohr's Autobiography, translated from the German (London, 1865; reprinted New York: Da Capo, 1969): vol. II, 128-30.

${ }_{27}$ See, for example, François-Sappey 'Pierre Marie François de Sales Baillot (1771-1842) par lui-même' and Penesco, 'Pierre Baillot et l'école franco-belge de violon'.

${ }^{28}$ See, for example, Chassain, 'Le Conservatoire'.

29 Penesco, 'Pierre Baillot et l'école franco-belge de violon', and 'Le violon en France au temps de Baillot et de Paganini', in La Musique en France à l'époque romantique, 199-229.

${ }^{30}$ Gessele, 'The Conservatoire de Musique and National Music Education in France'.

${ }^{31}$ Kailan Rubinoff, 'Toward a Revolutionary Model of Music Pedagogy: The Paris Conservatoire, Hugot and Wunderlich's Méthode de flûte, and the Disciplining of the Musician', Journal of Musicology 34/4 (2017): 473-514. 
the Conservatoire in 1795. She goes so far as to assert that the Conservatoire's teaching model was designed to produce instrumentalists who were incapable of playing anything other than what stood on the written page in front of them. ${ }^{32}$ Her thesis is persuasive, but however well it describes the case of the wind instruments, whose teachers did indeed come across wholesale from the Institut National de Musique, ${ }^{33}$ there are many ways in which it is not consistent with the evidence provided by Baillot's writings, nor by the memoirs of his students Sauzay and Dancla. ${ }^{34}$ To take one small example, the scale sections of the Méthode include a violin accompaniment written by Cherubini. This concern for their musical enlivenment hardly suggests the military style of technical drilling which Rubinoff identifies in the flute method (Fig. 3). The string teachers belonged to neither of the above institutional precursors of the Conservatoire, and Rubinoff does allow that the violin, given its prominent role as a solo instrument, may have formed a part-exception to her thesis. Nonetheless, her article provides a valuable reference point, both by virtue of its approach and for the conclusions she reaches as to the animating ideals of the Conservatoire.

In presenting the cultural context surrounding the publication of the official Conservatoire methods, Rubinoff chooses to focus on the military aspect, but there are at least two major cultural currents which were driving the Revolution well before armed conflict became a significant feature. The first was the attempt to put the ideas of the lumières into practice and to reorganize society along rational principles. Under the Directory, this tendency became associated most closely with the group of men led by Destutt de Tracy known as the idéologues, and one of its most prominent historians is François Azouvi. ${ }^{35}$ This is the tendency that gave rise in 1795-96 to the establishment of the Institut National, the École Normale and the associated institutions including the Conservatoire. The aim was the rational ordering of all human knowledge and its propagation, in other words, education. The standardization of weights and measures is part and parcel of this tendency, and I suggest that the Conservatoire publication of unified methods is at least as much its product as that of a military-style drive for control.

Just as relevant to the early Conservatoire is a competing current whose existence has been persuasively asserted by James Livesey. ${ }^{36}$ It is characterized by a different set of values, such as human feeling, connection and creative labour. With the downfall of the monarchy in 1793, the revolutionaries were conscious that the new republic could not be held together by reason alone. The people needed new symbols to encourage social cohesion, hence the revolutionary festivals. Livesey cites the speeches made at the Conservatoire prize-giving ceremonies by François de Neufchâteau, Minister for the Interior from 1797-99. The Minister held up the ideal of a music education that would nurture moral consciousness ${ }^{37}$ in

32 Rubinoff, 'Toward a Revolutionary Model of Music Pedagogy', 506.

33 For the exact figures, see Chassain-Dolliou, Le Conservatoire de Paris, ou les voies de la création, 18.

34 See, for example, Sauzay's description of lessons in Baillot's class at the Conservatoire: Sauzay and François-Sappey, 'La vie musicale à Paris', 166-7. See also Dancla on how Baillot often accompanied his students on his own violin: Dancla, Notes et Souvenirs, 57 . None of this suggests a military style of teaching on Baillot's part.

35 See, for example, François Azouvi, L'Institution de la raison: la révolution culturelle des idéologues (Paris: Libraire Philosophique J. Vrin, 1992).

36 Livesey, Making Democracy.

37 Livesey, Making Democracy, 230. 


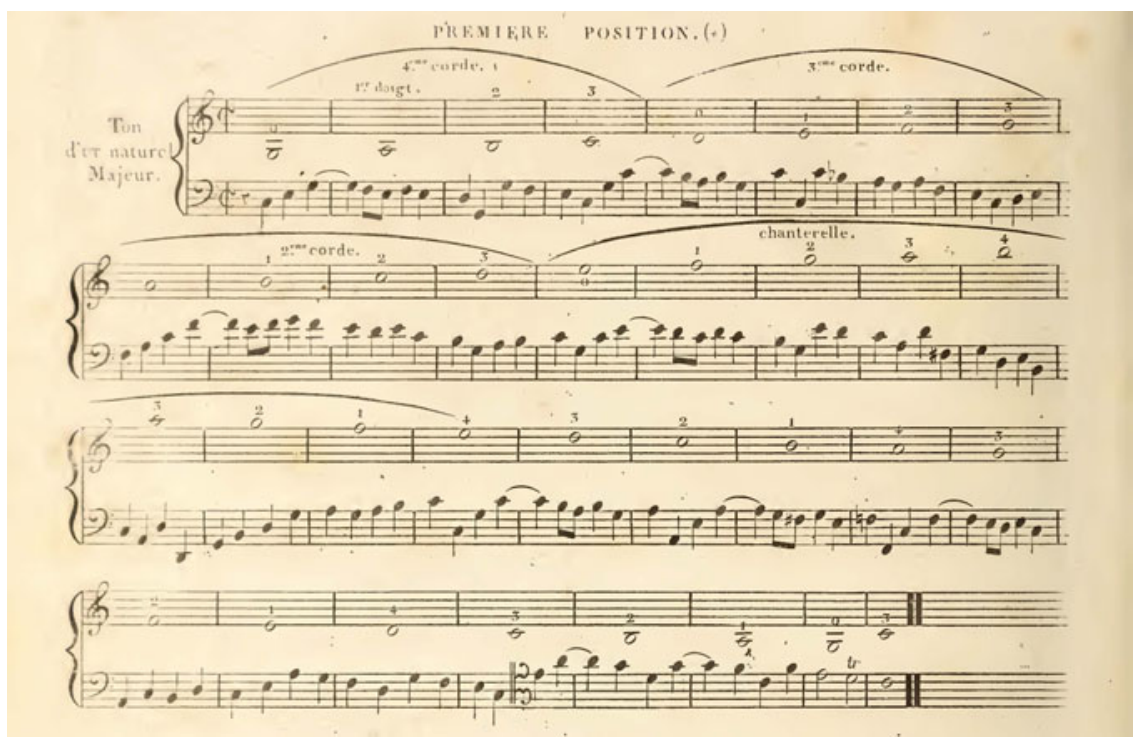

Fig. 3 First of scale exercises from the 1803 Méthode with accompaniment by Cherubini

language strikingly similar to that of the Baillot treatises. But the attempt to establish what Livesey calls the 'commercial republic' is not as idealistic as it may at first sound, proceeding as it does from the recognition that human beings are inherently social. The Conservatoire started out employing 115 teachers and aimed to provide free tuition to 600 students (it actually started with about 470). This was an extraordinary investment at the time, and it was not without opposition in the Council of Five Hundred. It makes more sense when one considers that sentiment was not merely the stuff of music and literature, but had a political value, and that education was just as central to this political project as to that of the idéologues. Rubinoff skips over these prize-day speeches of de Neufchâteau and instead quotes a speech given on a similar annual occasion in 1801 by Lucien Bonaparte. When Bonaparte identifies the mission of the institution as inspiring the French army to further victories, Rubinoff offers this as further evidence of an ingrained military ethos, whereas what it really demonstrates is the military takeover of the French state by Napoleon Bonaparte.

By the time he wrote L'Art du violon, Baillot and the Conservatoire had weathered not only Revolution and Empire, but the 1815 Bourbon Restoration and the July Revolution of 1830. The Conservatoire was a state-funded institution. It was always subject to the oversight of the relevant minister and his intendant, and often to their interference. It was thus particularly sensitive to changes in the political climate. Because of its revolutionary past, it suffered badly under the Restoration: its budget was cut, its director (Sarrette) sacked, its name changed of course to 'École royale' instead of Conservatoire, and its status downgraded through being brought under the menus plaisirs of the king's household. Cherubini, director from 1822 to 1842, managed to rebuild the institution. Though he fought fiercely for its independence, he still had to submit all candidates for vacant professorships to the Minister for approval, and he still had to suffer posts being created over his head, such as the appointment of Rossini to a new post of inspector of voice instruction in 1828. He only recovered the much-prized 
title 'Conservatoire' after the July Revolution. He threatened to resign in order to get his way many times and finally did so in February 1842, after being overruled on various aspects of the new regulations for the school. (He died a few months later, the same year as Baillot.) $)^{38}$

Having established the historical and scholarly contexts, I will now turn to the comparative analysis of the two documents.

\section{The Appeal to Tradition}

Like many of the preoccupations of the 1834 treatise, the appeal to tradition is present in 1803 in embryonic form, but the difference in prominence of this aspect is telling. The first page of the 1803 introduction gives a cursory history of the violin, including some speculation as to its link with three-stringed instruments of antiquity. The fourth paragraph then extols the variety of characters that can come from the instrument, citing some of the past masters of violin-playing:

Cet instrument, fait pour régner dans les concerts et pour obéïr à tous les élans du génie, a pris les différens caractères que les grand maîtres ont voulu lui donner : simple et mélodieux sous les doigts de CORELLI, harmonieux, touchant et plein de graces sous l'archet de TARTINI, aimable et suave sous celui de GAVINIÉS, noble et grandioso sous celui de PUGNANI, plein de feu, plein d'audace, pathétique et sublime entre les mains de VIOTTI, il s'est élevé jusqu'à peindre les passions avec énergie et avec cette noblesse qui convient au rang qu'il occupe et à l'empire qu'il exerce sur l'âme. ${ }^{39}$

This instrument, made to reign supreme over ensembles and to obey every flight of genius, has taken on different characters as required by the masters: simple and tuneful under the fingers of Corelli, harmonious, touching and graceful under the bow of Tartini, suave and amiable under that of Gaviniés, noble and grand under that of Pugnani, full of fire, full of audacity, pathetic and sublime in the hands of Viotti. It has risen as far as to depict the passions with energy and with a nobility matching its rank and the power it exercises over the soul.

Although the passage reminds us that the French School descends, via Viotti, from the purest Italian roots, the emphasis is on what the violin is capable of, rather than on the tradition itself.

The much more extensive appeal to tradition in the 1834 document is made up of a number of elements. The first and least important of these is a much more thoroughgoing attempt to trace the history of the instrument, which takes up two densely written pages, as opposed to two or three short paragraphs. More significant is the fact that, in adding the names of his recently deceased colleagues Kreutzer and Rode to the list of masters quoted above, and in lamenting their passing, Baillot appeals directly to their former pupils to preserve their traditions: 'leurs talens revivront en vous : conservateurs de leur traditions, vous empêcherez que l'oubli ne pose sa main glacée sur leurs ouvrages' (In you, their talents will live again: as conservators of their traditions, you will prevent the chill hand of

38 Anik Devriès-Lesure, 'Cherubini directeur du Conservatoire de musique et de déclamation', in Conservatoire de Paris: Des menus-plaisirs à la cité de la musique, ed. Bongrain, 39-98.

39 Baillot, Méthode, 1. 
forgetfulness from falling on their works). ${ }^{40}$ Tradition is no longer merely an inspiration, it is an obligation.

This sense of veneration for tradition is further reinforced by a 'catalogue', in the appendices, of living and dead composers whose works are used in teaching at the Conservatoire (Fig. 4). ${ }^{41}$ The catalogue is divided into two tables. First, significantly, come the dead composers, listed in chronological order by year of birth, and second the living composers, listed alphabetically by surname. This list of 23 dead composers signals a seismic shift from the situation which held until the end of the eighteenth century, when performers basically only played their own works, and scarcely any dead composers received a hearing. ${ }^{42}$ Italians dominate this list; only Leclair, Gaviniès, Rode and Kreutzer (the last three professors at the Conservatoire) appear for the French. The five Germans are Bach, Handel, Haydn, Mozart and Beethoven; one can sense a canon in the process of formation. ${ }^{43}$ The list of 22 living composers tells another part of the story: only Campagnoli and Paganini for the Italians (more on Paganini later), and only Guhr and Spohr from Germany. The other 18 appear to be French or Belgian.

Baillot and Spohr, incidentally, are the first great exponents of the new art of 'interpretation': violinists not only capable of playing their own works but also of adapting their playing to the varied styles of other composers. ${ }^{44}$ It is this ability that is extolled by Baillot under the rubric of 'le génie d'exécution'. Since this section is to be found in Part Two of both the 1803 and 1834 treatises, I will not go into the idea further here except to note that it was a pioneering one in 1803. It was one of the things that separated Baillot and Spohr from Paganini, whose success was built on the performance of his own works in public, and whose style appeared less adaptable. ${ }^{45}$ It may also have separated Baillot from his colleagues Rode and Kreutzer. Apart from playing the works of his master, Viotti, Rode largely performed his own compositions, and his attempt to play the Beethoven Violin and Piano Sonata Opus 96 dedicated to him famously failed to meet with the composer's approval.

It should be noted that Baillot did not invent the idea of gathering together works of the old masters for the purpose of study. L'art du violon, published by Jean-Baptiste Cartier five years earlier than the Méthode, is principally composed

40 Baillot, L'Art du violon, 5.

41 Baillot, L'Art du violon, 271.

42 See, for example, Roger Norrington's preface to Brown, Classical and Romantic Performing Practice: 'before 1800 there simply was no historical repertoire at all ... As a repertoire began to develop from the time of Beethoven's symphonies'.

43 See Tia DeNora, Beethoven and the Construction of Genius: Musical Politics in Vienna, 1792-1803 (Berkeley: University of California Press, 1995). Baillot and his colleagues seem to have contributed to the spread of the canon first established in Vienna. For the role of the exercices publiques in promoting the music of Mozart and Beethoven in particular, as well as instrumental music in general, see Jean Mongrédien, 'Les prémiers exercices publics d'élèves d'après la presse contemporaine (1800-1815)', in Conservatoire de Paris: Des menusplaisirs à la cité de la musique, ed. Bongrain, 153-7.

44 This is what Boris Schwartz calls the 're-creative artist', see Schwartz, French Instrumental Music Between the Revolutions, 203. Schwartz here is writing of Baillot; many have made this point about Spohr, see, for example, Brown, Classical and Romantic Performance Practice, 272.

45 See, for example, Penesco, 'Le violon en France au temps de Baillot et de Paganini', 216. 


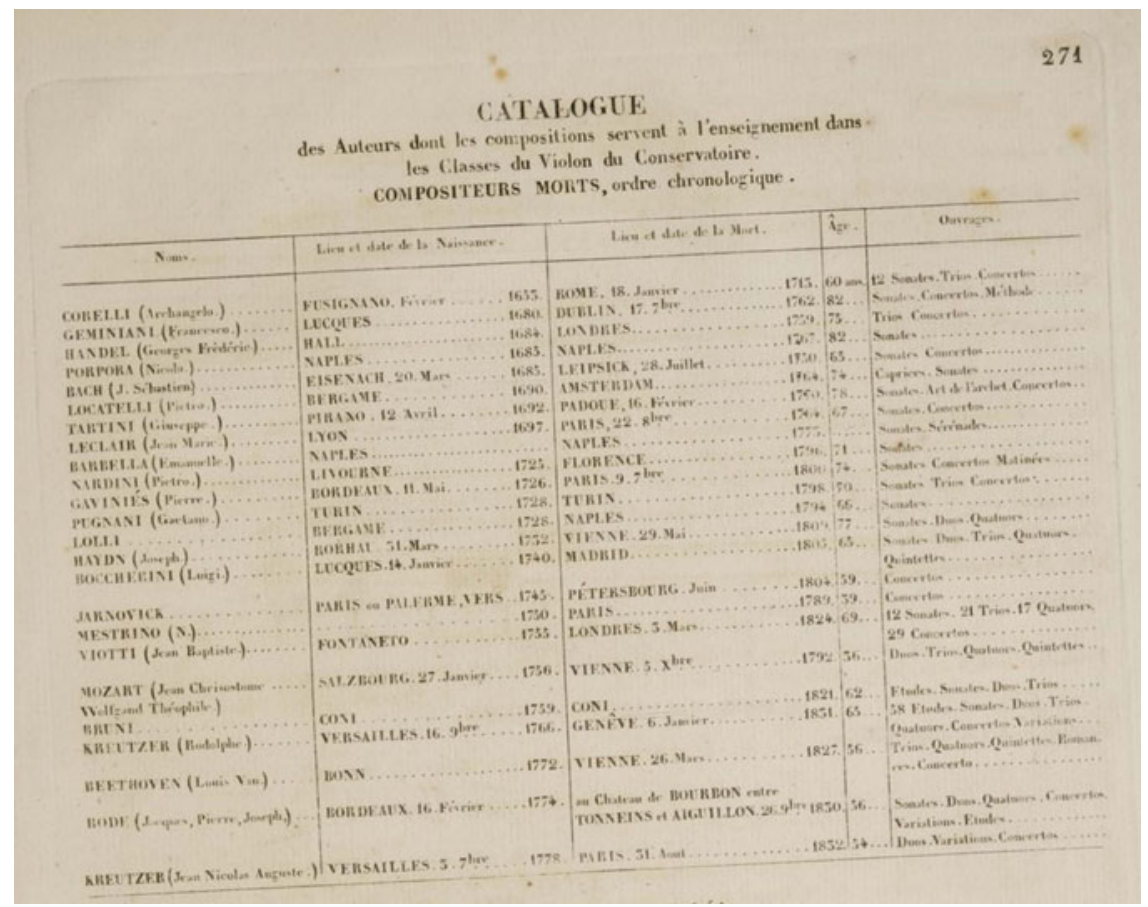

Fig. 4 Catalogue from L'Art du violon of dead composers whose works were used in the violin classes.

of just such a collection. ${ }^{46}$ Dedicated to the Conservatoire and formally reviewed by its violin professors (including Baillot), L'art $d u$ violon was accepted by the Conservatoire administration in 1798 and deposited in its library, as the manuscript edition shows. ${ }^{47}$ In it, Cartier even thanks Baillot and Gaviniès for their contributions to the collection. ${ }^{48}$ Baillot chose to make no reference to it, however, or to its principles, in drafting the 1803 Méthode.

Baillot's 1834 treatise, by contrast, goes much further than Cartier's in its reference to the tradition: every lesson through the body of the treatise is illustrated by musical examples taken from existing works (Fig. 5). In combination with the generally greater reach of the mature treatise, it is largely this procedure that accounts for its greater length, given that the long scale sections from the earlier work have actually been reduced. The procedure is announced in the foreword with this note:

Presque tous les exemples ont été tirés des auteurs considérés comme classiques, leurs ouvrages pouvant servir de type dans chaque genre : nous avons cru qu'il

${ }^{46}$ Jean-Baptiste Cartier, L'art du violon, ou Collection choisi dans les sonates des écoles italienne, française et allemande (Paris, 1798).

${ }_{47}$ 'Extrait des régistres des délibérations de l'administration du Conservatoire de Musique, Séance du 13 Floréal, an 6 de la République Française', Cartier, L'art du violon, page preceding page 1 .

48 Cartier, L'art du violon, 1. 
74

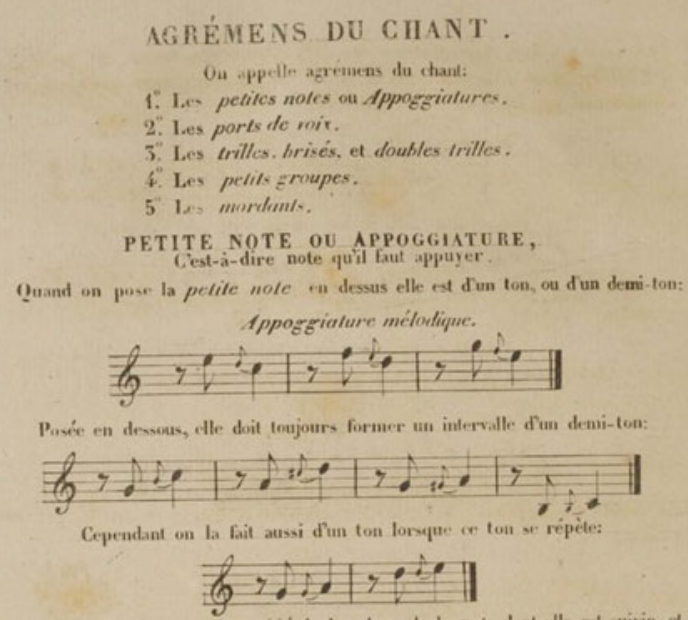

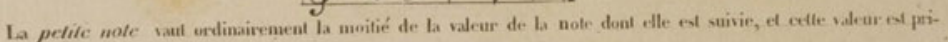
ar sur celle de celle note même.

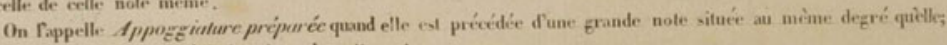
on lui danne bujours ba moitie de la valeur de cette note:

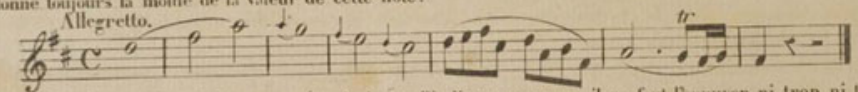

LAppozgiature devant ètre appuyce, ainsi que Mindique son nom, it ne faut Pspuyer ni trop ni trop peu pour ne point ewérer ou affaiblir son caractère doux et affertueus.

Par une conséquence de Pacosat donné à l'Appoggiature on deil faire entendre faiblement la note qui la suit.

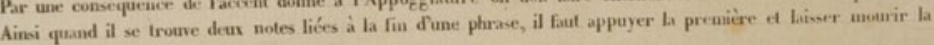
seconde comme un $c$ muet.

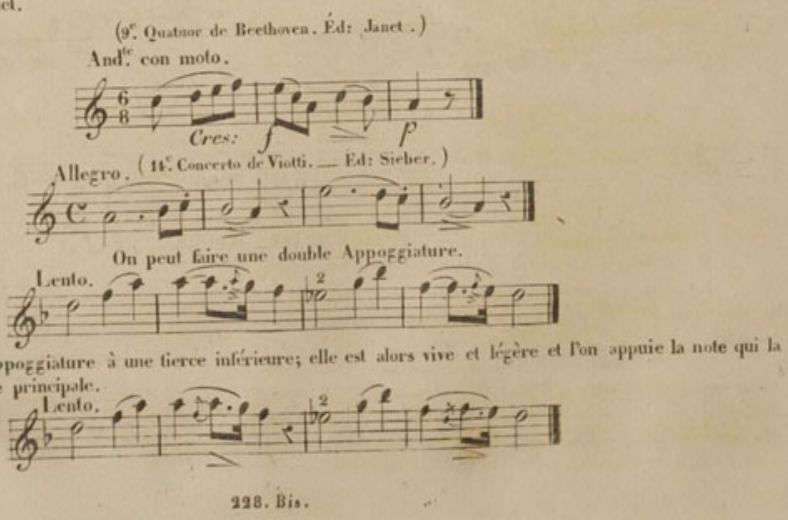

Fig 5 Excerpt from the section on ornaments (agréments de chant) from L'Art du violon, with examples from Beethoven and Viotti.

valait mieux procéder ainsi du connu à l'inconnu, que d'offrir des exemples dont l'application ne serait pas aussi claire, aussi positive, ni par conséquent aussi efficace; ces exemples ne pouvant avoir pour eux l'autorité du temps et de l'usage.

Almost all the examples have been drawn from authors considered classical, in that their works can serve as typical of each genre: it is our belief that it is better to proceed thus from the known to the unknown than to offer examples whose application would not be as clear, as positive, and therefore as effective. Such examples would not carry the authority of time and usage. 
'The authority of time': here we have the change in a nutshell. The 1803 Méthode is, like the Conservatoire itself, a product of the Revolution: it evinces no respect for the authority of time. Taken as a whole, it consists principally of a long series of scale exercises framed by a number of technical and aesthetic principles enunciated for the most part in an ahistorical way. It contains sentiments like the following, from the introduction, explaining how the violin came to occupy its current lofty position: 'Pour en venir à ce point, il a fallu franchir les barrières qu'opposait la routine, et à mettre des beautés de sentimens à la place de ces beautés de convention' (To reach this point, the barriers posed by routine had to be breached, and beauties of sentiment had to replace those of convention). 'Routine' here is synonymous with 'privilege', with l'ancien régime, with tradition in fact, but tradition as an obstacle to progress. The second half of the sentence is decidedly Rousseauvian, recalling the Lettre sur la Musique Française of 1753, with its vitriolic attack on the mannered style of Lully and Rameau in favour of the simpler, more 'natural' Italian style. ${ }^{49}$ Encapsulating both the political and cultural revolutions of later eighteenth-century France, the sentence is also one of only two passages which do not migrate from the Méthode to L'Art du violon, its revolutionary flavour no longer appropriate in 1834.

Baillot remained a disciple of Rousseau - the distinction between 'taste' and 'genius' in both treatises is taken almost word for word from Rousseau's Dictionaire de Musique $e^{50}$ - but the sophisticated treatment of nuance and the means to communicate affect in $L^{\prime} A r t d u$ violon go beyond a simple binary opposition of the natural and the conventional. Furthermore, in the 1834 treatise, there are signs that taste, inborn or developed with the aid of the master, ${ }^{51}$ is not a sufficient arbiter. The productive tension between genius and taste remains, but time, 'which alone teaches us the true value of things', ${ }^{\prime 2}$ is drafted into service as an additional restraint on that genius which is creative but which can lead us astray: 'Il appartient donc au génie de créer les effets nouveaux, au goût d'en régler l'emploi et au temps seul de les sanctionner' (Genius thus has the task of creating new effects, taste of regulating their usage, and time alone of giving them sanction). ${ }^{53}$

The ahistorical flavour of the Méthode is consistent with a revolutionary culture which thought it could erase history and make a new beginning at Year One. It is true that, in 1803, Napoléon was about to be crowned emperor and the political aspects of the Revolution were being steadily wound back. At the cultural level, however, the language and probably much of the aspiration remained. ${ }^{54}$ The official version of the Méthode records the formalities by which 'citizens Baillot, Kreutzer and Rode' were tasked with its preparation, its endorsement by the governing commission, and its formal adoption by the Conservatoire as announced by

49 Jean-Jacques Rousseau, Lettre sur la Musique Française in Collection complète des œuvres, Genève, 1781-1789, online edition at www.rousseauonline.ch, version from 7 October 2012.

50 'Le genie crée, mais le goût choisit' (genius creates, but taste chooses): entry for 'goût', in Jean-Jacques Rousseau, Dictionnaire de Musique (Paris, 1768): 236.

51 See 1803 , p. 161, and 1834, p. 265.

52 'Le temps seul nous apprend la juste valeur des choses nouvelles': Baillot, L'Art du violon, 7 .

53 Baillot, L'Art du violon, 6.

54 As an example, the ultimately futile effort to impose the Revolutionary calendar actually intensified under the Directory and was not abandoned until 1804. See Bronislaw Backo, 'le calendrier republicain', in Pierre Nora, ed., Les Lieux de Mémoire, Vol 1: La République (Paris: Gallimard, 1984): 37-84. 
the director, Bernard Sarrette (and dated 'le 5 ventose an 10'). ${ }^{55}$ The Méthode is attributed to the three violinists not just because of Baillot's legendary modesty, but because of the ideal of collective action. ${ }^{56}$ While it is tempting to be cynical about this Revolutionary preoccupation, one can also argue that, in the case of the new violin school, it was a reality. The task of writing the Méthode may have fallen to Baillot as the most able in this area - he also entered public debate in defence of the young institution ${ }^{57}$ - but the three colleagues contributed equally to the fame of the school. Until his return from Russia in 1808, Rode was the most famous as a performer, and much like Viotti, his influence as a model may have been greater than his direct influence through teaching. The young Spohr modelled his playing on Rode's, and through Joseph Böhm Rode's influence extended to the new school in Vienna. Kreutzer was the most prominent and versatile composer of the three; he was famed for his ability to improvise and included among his pupils Lambert Massart, teacher in turn of Henryk Wieniawski. Baillot was the most versatile player of the three, the most famed as an interpreter of others' music, and the most gifted with a pen.

The 1803 treatise may have been drafted in some haste. Not only was it a priority for the Conservatoire to issue methods for all the instruments taught in order to establish a coherent basis for instruction, but Baillot was a very busy man. He was occupied with the struggle to establish his musical career and support a large extended family, ${ }^{58}$ and he even found time to co-write the violoncello method. ${ }^{59}$ This may in part explain the brevity of the Méthode. The fact remains, however, that it does outline a philosophical and aesthetic position, and it does so with scarcely an appeal to tradition. The 1834 treatise, on the other hand, is saturated with historical reference. The 1803 document is part of an attempt to establish a tradition, the 1834 treatise to defend that tradition. As we shall see when we come to the case of Paganini, it is a tradition defined not only by what it includes, but also by what it excludes.

\section{Nationalism}

As noted above, cultural nationalism was at the heart of the Conservatoire enterprise. There was an evident desire for the institution to contribute to the glory of France. The violin school certainly succeeded in this, and within a short space of time, the 'School of Viotti', as it was initially known, set the standard for bowing technique, taste, and virtuosity. It is no accident that the last two Beethoven sonatas for piano and violin were dedicated to Kreutzer and Rode respectively; and, as Boris Schwartz has shown, the Violin Concerto is strongly influenced by the concerto writing of Viotti and Rode. ${ }^{60}$ The fame of the School rested on more than the

55 Baillot, Méthode, page prior to 1.

56 Chassain, 'Le Conservatoire', 16.

57 François-Sappey, 'Pierre Marie François de Sales Baillot (1771-1842) par lui-même', 128.

58 François-Sappey, 'Pierre Marie François de Sales Baillot (1771-1842) par lui-même', esp. 134-50.

59 Brigitte François-Sappey, "“Le salon des réfusés"' in Le Conservatoire de Paris: deux cents ans de pédagogie, ed. Bongrain and Poirier, 31.

60 See, for example, Schwartz, French Instrumental Music Between the Revolutions, chap. 4. Clive Brown asserts that it is even more influenced by the style of Franz Clement, the work's 
solo performance of its leading exponents, however. The orchestral concerts given by the students of the Conservatoire in the new century, the exercices publiques, were renowned for the fire and accuracy of the violin playing in particular, as attested by a succession of visitors including Spohr, Mendelssohn and Liszt, even if German listeners often felt that the French played every allegro too fast. ${ }^{61}$ Here is Mendelssohn: 'The school of Baillot, Rode or Kreutzer provides them with violinists and it is a pleasure to see these young men all start playing with the same attack, in the same manner and with the same fire' ${ }^{62}$

Unfortunately, what Laetitia Chassain calls 'the autarchic ideal' could easily and did - become protectionist under the pressures of the Bourbon Restoration, when, as a Revolutionary institution, the Conservatoire found itself under attack. ${ }^{63}$ This was a time when foreigners were forbidden entry into the Conservatoire. When Franz Liszt was brought by his father to Paris in 1823, Director Cherubini, despite his being a foreigner himself and in spite of the young man's manifest talent, refused to relax this rule. Only thirty years later, one of the most famous representatives of the violin school would be the Pole Henryk Wieniawski, but in the meantime admirers of German music, like Hector Berlioz, could struggle to make their way, and even the music of Beethoven met with stiff resistance from French composers as well as from the public. Berlioz describes in detail 'l'ironie et les réticences des compositeurs français et italiens, fort peu ravis de voir ériger un temple à un Allemand dont il considéraient les compositions comme les monstruosités, redoutables néanmoins pour eux et leur école' (the reticence and irony of the French and Italian composers, who were little pleased to see a temple erected to a German, whose compositions they regarded as monstrosities, but dangerous for them and their school nonetheless). ${ }^{64}$

The fame of the new school also seems to have bred considerable complacency on the part of the Paris public, as witnessed by the critical reception of Louis Spohr's performances during his visit to Paris in $1820 .^{65}$ It does not seem from Spohr's own account that this complacency extended to his French colleagues. It would be unwise to impute the views of the Paris reviewers, let alone those of the musical public at large, to the Conservatoire violinists. After all, it was Baillot and his pupil Habeneck who championed the instrumental music of Beethoven, and Baillot was a pioneer in the performance of chamber music, especially that of Beethoven, Haydn, and Mozart. ${ }^{66}$

dedicatee; see the preface to his edition of Clement's D Major Violin Concerto of 1805 (Madison: A-R Editions, 2005): ix-x.

${ }^{61}$ Schwartz, French Instrumental Music Between the Revolutions, chap. 1 and 2. Die Allgemeine Musikalische Zeitung (Breitkopf and Härtel: Leipzig, 1798-1848) is an important source.

62 Mendelssohn as quoted by Chassain, 'Le Conservatoire', 22; my translation from her French.

${ }^{63}$ Chassain, 'Le Conservatoire', 19. 'Autarchic' has more than one meaning. Here the translation from the French could also be 'the ideal of national self-sufficiency'.

${ }^{64}$ Berlioz, Mémoires, vol. 1, 137-9.

65 A much-quoted journal review praised the purity and accuracy of his playing but went on to recommend 'that he remain a while in Paris in order to perfect his taste so that he can return to Germany and educate his countrymen'. See, for example, Louis Spohr's Autobiography, vol. II, 123.

66 François-Sappey, 'Pierre Marie François de Sales Baillot (1771-1842) par lui-même', 186-91. See also the passage of Berlioz's Mémoires cited above. 
Nonetheless, one can see within the two treatises under discussion signs of a change in the attitude to foreigners. The first is that one of only two passages of text which fail to find their way from the introduction of the 1803 Méthode to the 1834 Art $d u$ violon lists among the necessary qualities of the true artist that he is open to learning from musicians from other countries:

il va chez ses voisins pour y puiser de nouvelles sources de connaissances dont il revient enrichir sa patrie : avide de choses nouvelles, curieux de tout ce qui peut aggrandir ses idées, il accueille l'étranger avec ce sentiment de fraternité que donne l'amour des arts et cet empressement qui tient au désir d'apprendre : trop sensible et trop fier pour être jaloux, il regarde comme une conquête pour l'art le succès d'un nouveaux talent, et ne connaissant que la noble émulation, il fait de ses rivaux ses amis. ${ }^{67}$

he goes to his neighbours to draw on new sources of knowledge which he brings back to his own country. Eager for novelty, curious about everything which can add to his ideas, he welcomes the foreigner with that brotherly feeling which comes from a love of the arts and that eagerness which comes from the desire to learn. Too sensitive and too proud to be jealous, he sees the success of a new talent as a triumph for art, and knowing only the nobility of emulation, he makes friends of his rivals.

Seeking to learn from his neighbours is, of course, exactly what Cartier had done in his 1798 treatise: as well as collecting violin compositions from a selection of Italian, French, and German composers, he set out explicitly to bring together the best approaches from the existing violin methods of the three national traditions. ${ }^{68}$ Baillot and his colleagues chose not to emulate this approach for the 1803 Méthode. No doubt they felt that they were proceeding from universal principles, a purer procedure than some compromise between national traditions, but the statement of brotherly love and openness remains. Perhaps it was mere oversight that this statement fails to find its way into L'Art du violon. There is, however, something at the conclusion of the 1834 introduction which may be said to replace it: the expression of a wish for music festivals in France of the kind that already existed in England and Germany. Baillot characterizes these as a kind of Olympic games of music, but as an affair internal to the nation. The language of emulation, of the positive value of rivalry, is transposed here into a purely national context:

L'émulation est un des plus grands ressorts de ces institutions [i.e., 'ces solennités'] et l'art gagne toujours aux rivalités : la rivalité d'ailleurs, perdant tout de ce qu'il y a $\mathrm{d}$ 'hostile, agit en faveur de l'union, le combat tourne au profit de tous les combattans, le bonheur commun est la récompense du parti vainqueur, et l'art seul étend sa domination, aspirant toujours à de nouveaux triomphes.

Emulation is one of the greatest motivators of these institutions [i.e., 'festivals']. Art always benefits from rivalry; moreover, as this kind of rivalry loses any hostility it might have, it acts to promote unity: the contest turns to the profit of all the contestants, collective happiness is the prize of the victors, and art alone extends its dominion, aspiring always to new triumphs.

67 Baillot, Méthode, 3.

68 Cartier, L'art du violon, Preface, esp. 2. His main sources are Geminiani for the Italian school, Leopold Mozart for the German school, and de Tarrade and L'abbé 'fils' for the French. 
One senses the fatigue that followed Waterloo, the end of France's attempts to extend its dominion over the rest of Europe. It is hardly surprising that a certain inwardness should follow such a period.

\section{Paganini}

Before considering the key new section in L'Art du violon called 'Progrès de l'art', we need to recall the name of the shadow hanging over it. Paganini's much-anticipated arrival in Paris in 1831 was a runaway public success. The Italian celebrity gave 12 concerts in Paris in 1831 and returned in 1832 to give another ten. Given the well-known difficulty of making concerts pay in Paris, ${ }^{69}$ this gives an idea of the scale of his success. The Paris reviewers, such as Berlioz, were in raptures, and the stocks of the local violinists fell sharply. ${ }^{70}$ Even a conservative authority like François-Joseph Fétis had to acknowledge not only the technical virtuosity of Paganini, but also the expressiveness of his playing, though he still gave preference to Baillot's more restrained and intimate style. He famously asserted that Baillot was the only violinist who stood comparison with Paganini if heard on his own ground. ${ }^{71}$ It is interesting, however, that in 1820 Spohr considered Lafont the most admirable of the Paris violinists, and found Baillot's playing rather mannered. ${ }^{72}$ Of all the Paris violinists of the time, Lafont was the one most influenced by Paganini, even appearing in the same concert as Paganini in Milan in 1816 , an occasion inevitably billed as a 'violinistic duel' by the locals. ${ }^{73}$

There is a contradiction implicit in the founding of a revolutionary institution, and L'Art du violon shows signs of the tensions inherent in the enterprise. How does one prevent an institution that aspires to set standards from becoming conservative, from retarding progress rather than fostering it? According to Schwartz, this is exactly what happened to the French School within the first 30 years of its establishment. He asserts the existence of 'staleness' and 'violinistic inbreeding' among the violinists around the Conservatoire, until the appearance of Paganini in Paris in 1831 'tore the French violinists out of their smug complacency'. ${ }^{74}$ This is consistent with Schwartz's general thesis that, after some innovation in operatic composition by the 'Revolutionary romanticists' in the 1790s, French composition failed to bring forth anything new until the 1830s, a state of affairs which paralleled the conservative cultural climate under the Empire and the Restoration. In 1833 even Fétis claimed, from his new perch in Brussels, that the Paris Conservatoire students were being stifled under the weight of tradition. ${ }^{75}$

I see no reason to doubt Baillot's professed generosity towards a rival as an artist, $^{76}$ but it is clear from the 1834 introduction that, as a pedagogue and as the

69 See, for example, Louis Spohr's Autobiography, 120.

70 Penesco, 'Le violon en France au temps de Baillot et de Paganini', 201-3.

71 Penesco, 'Pierre Baillot et l'école franco-belge de violon', 92-3.

72 Louis Spohr's Autobiography, 128-30.

73 Schwartz, French Instrumental Music Between the Revolutions, 215.

74 Schwartz, French Instrumental Music Between the Revolutions, 216.

75 Henri Vanhulst, 'Le Conservatoire royal de musique de Bruxelles: ses origines et le directorat de François-Joseph Fétis (1833-1871)', in Le Conservatoire de Paris: Des menusplaisirs à la cité de la musique, ed. Bongrain, 208.

76 There is correspondence that testifies to Baillot's admiration of Paganini's qualities as a performer in spite of his discomfort with Paganini's style, see François-Sappey, 'Pierre Marie François de Sales Baillot (1771-1842) par lui-même', 185. 
spokesman for the Conservatoire 'system', he felt the need to distance himself from any endorsement of Paganini's style. He does this obliquely, under the heading of taste, having acknowledged Paganini's recent success. Beneath the politeness of the text, however, his meaning is clear: Paganini's playing is entirely idiosyncratic, is in questionable taste, and is not to be taken as an example. Furthermore, much of Paganini's success is built on technical tricks which appear new, but are not in fact so. It appears that while the true artist always welcomes a rival, a school may not:

Inscrire dans cet ouvrage le nom de $\mathrm{M}^{\mathrm{r}}$. Paganini au moment où les succès qu'il vient d'obtenir à Paris justifient sa réputation est pour nous un devoir et un honneur indépendamment du plaisir que nous éprouvons à lui rendre justice.

On a vu du premier abord que sa manière de jouer du violon était, en général, toute à lui, et n'avait que peu de ressemblance avec celle des autres virtuoses : cette différence donne à son jeu le piquant de la nouveauté, et cependant ce jeu repose presqu'entièrement sur l'emploi de certaines difficultés dont on a fait usage autrefois ...

Il est une observation à faire ici; c'est que, le plus souvent, l'art perd d'un côté ce qu'il gagne de l'autre ... cependant, le génie peut tout employer avec succès pourvu que ce soit avec mesure, c'est à dire, pourvu qu'il ne passe point de certaines limites que le goût doit fixer...

$\mathrm{M}^{\mathrm{r}}$. Guhr, de Francfort, a fait paraître un ouvrage dans lequel on trouvera la plupart des procédés employés par $\mathrm{M}^{\mathrm{r}}$. Paganini; cet ouvrage donne l'explication la plus détaillée des principaux passages et des effets qui particularisent son jeu; il ne doit point être considéré comme faisant suite à la méthode du Conservatoire, composée dans un tout autre système. ${ }^{77}$

To include in this work the name of Mr Paganini at the moment when the success he has just obtained in Paris justifies his reputation, is a duty and honour for us, quite apart from the pleasure we feel in doing him justice.

One could see straight away that his manner of playing was, generally speaking, entirely his own, and bore little resemblance to that of any other virtuoso. This difference lends his playing an attractive novelty which in fact is built almost entirely on the use of certain technical difficulties which were formerly in usage ...

There is an important observation to be made here, which is that art often loses on the one side what it gains on the other ... An artist of genius, however, can make successful use of anything, provide that he does so in moderation, that is to say, so long as he does not go beyond certain limits dictated by taste.

$\mathrm{Mr}$ Guhr of Frankfurt has recently published a book in which one can find most of the technical skills displayed by Mr Paganini. This work gives a most detailed explanation of the principal passages and the effects which make his playing so distinctive. It should not in any way be considered as a continuation of the Conservatoire method, which is built on a totally different system.

\section{The Perils of Progress}

Baillot's rejection of Paganini in 1834 is consistent with the aesthetic principles laid out in 1803, such as the relationship between genius and taste. But it is clear that these very principles create problems for him when it comes to the question of

77 Baillot, L'Art du violon, 6. 
progress. One of the attractive, classical features of the philosophy of L'Art du violon is Baillot's constant striving for balance: between genius and taste, between sense and sensibility, between conscientious study of the written score and the inspiration of the moment. He in no way comes across as a pedant; he has a respect for the limitations of analysis. ${ }^{78}$ In these things, his philosophy recalls that of the later Goethe. He welcomes the invention of the metronome for the assistance it can give in inculcating a constant sense of tempo, but cautions that the musician must be able to depart from it as the music demands. ${ }^{79}$ In like spirit, he counsels against over-practise of bow division, lest it lead to coldness in execution. ${ }^{80}$ His attitude to genius is more generous than that of Rousseau, ${ }^{81}$ in that genius is not for him a quality simply inborn: his génie d'exécution is clearly presented as something to which the student might aspire, although he does not go as far as Goethe's 'Genie ist fleiss' (Genius is hard work). He was a man of great youthful enthusiasms, with a strong sense of duty and a generous spirit, and from his letters seems to have been a very affectionate family man. ${ }^{82}$ All of this was despite a life battered by political and economic turmoil in which he struggled to make a living from his art. It is little wonder that French musicologists such as François-Sappey and Penesco ${ }^{83}$ write of him with veneration.

On the face of it, Baillot strikes a judicious balance between a respect for tradition and an encouragement of innovation. In the section 'Progrès de $1^{\prime}$ art ${ }^{\prime 84}$ he states that art cannot stand still, that technique must develop in response to changing musical demands, and that the human tendency to strive is inborn. As Penesco points out, Baillot shows himself very open to experimentation when it comes to techniques such as scordatura (non-standard tuning of the strings) and novel ways of bowing quadruple stops. ${ }^{85}$ But Baillot is not so open when it comes to matters of taste. Not all progress is good: 'Étudions sans cesse la marche de l'art, multiplions les essais : s'il avance, favorisons tous les mouvemens; s'il est prêt à reculer, faisons nos efforts pour le retenir (Let us study unceasingly the progress of art, let us increase our efforts: if there is progress, let us encourage its movement; if it is ready to retreat, let us strive to hold it steady). ${ }^{86}$

Baillot's greatest bugbear is empty virtuosity, but this is not all: innovations must be rejected if they are not consonant with the essential character of the violin, which is 'beautiful, noble and touching'. ${ }^{87}$ With the rapid rise of the Romantic

78 For example: 'la musique tenant à nos sensations les plus intimes, participe à tout de ce qu'elles ont de vague et d'indéfinissable' (since music relates to our most intimate feelings, it is part of all their vagueness and indefinability), L'Art du violon, 7.

79 Baillot, L'Art du violon, 252.

80 Baillot, L'Art du violon, 92.

81 Rousseau, Dictionnaire, entry for 'génie', 230.

82 See François-Sappey, 'Pierre Marie François de Sales Baillot (1771-1842) par lui-même'. All of these qualities come through very clearly through the letters held by Baillot's descendants as quoted by François-Sappey and through Baillot's actions. Witness for example the story of his attempt to resign his appointment at the Conservatoire in 1799 on Rode's return from absence, 141-2.

83 See in particular Penesco, 'Pierre Baillot et l'école franco-belge de violon'.

84 Baillot, L'Art du violon, 6-10.

85 Penesco, 'Pierre Baillot et l'école franco-belge de violon', 94.

86 Baillot, L'Art du violon, 7.

87 Baillot, L'Art du violon, 8. 
aesthetic from 1830 on, this could rule out much of the new. For an example, what room does it leave for the demonic, for a later work from the Franco-Belgian tradition $^{88}$ like Eugène Ysayë's famous 'Obsession' (the first movement of his Sonata Op. 27 No. 2 for Solo Violin)? Or to take an orchestral example, Berlioz's Symphonie Fantastique, which received its first performance at about the same time Baillot was writing L'Art du violon, and which, incidentally, may have provided some of the inspiration for Ysayë, with its striking use of the mediaeval Dies irae sequence? The resistance of the musical establishment to Berlioz was due not only to his gift for personal provocation, but also to the revolution in style represented by his music. It is hardly a coincidence that one of Berlioz's most implacable opponents, the composer, theoretician, musicologist and reviewer Fétis, was a much-quoted admirer of Baillot. ${ }^{89}$ To reject all that is not 'beautiful, noble and touching' is effectively to hold fast to the Viotti aesthetic. It is all very well to note wisely that one 'must not get stuck in the narrow path of routine', but it was 1845 before violinists were allowed to present any concerto in the Conservatoire competitions but one of Viotti's. This, in spite of the warning in 'Progrès de l'art' that even Viotti cannot be considered the last word as a violinist. ${ }^{91}$ What we witness here, along with a laudable determination to acknowledge the uniqueness of each individual, is the tendency of institutions to inertia. While Baillot can accept the mortality of the master, he cannot accept the mortality of his style.

Baillot's principles may be admirable, but they are not timeless, and many of the things he stands against were precisely those which were in vogue in the 1830s. The rapid rise of the virtuoso, for example, brought with it the appearance of increasing numbers of child prodigies, whereas Baillot warns against the promotion of 'precocious talents' ${ }^{92}$ Like Baillot, Fétis inveighed against the new virtuosic trend in his Biographie universelle des musiciens, but as Anne Rousselin-Lacombe points out, the validity of his binary opposition of 'music' and 'virtuosity' is questionable. ${ }^{93}$ Paganini did not merely make large amounts of money from a gullible public, his music and his playing inspired many fellow composers. Berlioz wrote Harold in Italy for Paganini (even if it did not turn out to be the kind of composition Paganini had in mind), ${ }^{94}$ and Brahms, Liszt and Rachmaninov all wrote their own virtuosic sets of variations on the theme of the Twenty-Fourth Caprice.

It is interesting that, where the Méthode simply extols the pre-eminence of the violin, L'Art $d u$ violon acknowledges the rise of the piano and states that violin and piano 'share the domain of music'. ${ }^{95}$ In this, the 1834 treatise does mirror the times. Rousselin-Lacombe emphasizes the role of the growing middle-class

88 Because of the interchange which developed between them, it is customary to treat the violin schools of Paris and Brussels schools as a single 'Franco-Belgian school'; but see the Conclusion below.

89 Penesco, 'Pierre Baillot et l'école franco-belge de violon', 93.

90 'Gardons-nous donc de rester jamais dans l'étroit sentier de la routine', Baillot, L'Art du violon, 7 .

91 Baillot, L'Art du violon, 8.

92 'Talens précoces', under 'Manière de travailler', in Baillot, L'Art du violon, 242.

93 Anne Rousselin-Lacombe, 'Piano et pianistes', in La Musique en France à l'époque romantique, 137.

94 Berlioz, Mémoires, vol. 2, 31-35.

95 'Le violon et le piano partagent aujourd'hui l'empire de la musique instrumentale', Baillot, L'Art du violon, 8. 
public in encouraging piano-playing in general and virtuosity in piano performance in particular. ${ }^{96}$ The changing social context is a very important part of the success of Paganini, as well as of the critical resistance to that success. After the concert tours in the early years of the new century, much of Baillot's performance was done in private contexts. When Spohr came to Paris, he first met and played for the Paris violinists in private gatherings before essaying a public concert. ${ }^{97}$ Similarly, almost all the performances during Spohr's early tour through the Courland with Franz Eck were held in private houses of music friends. When Spohr met Paganini in Venice (1816), however, the latter refused to play anything at a private gathering, explaining that 'his style of playing was calculated for the great public only'. ${ }^{98}$ So what we have is an opposition not only between aesthetic approaches, but also between modes of music consumption. Baillot and Fétis stand for the noble gesture rather than the extravagant, for restraint rather than excess, for modesty rather than self-promotion. Paganini made his living through his public concerts; self-promotion was for him an economic necessity. Baillot and his colleagues made theirs through appointments royal, republican, or imperial: they only had to convince the few of their worth.

This cultural contest and change is the backdrop against which we must read 'Progrès de l'art'. Like the founders of the Académie Française, Baillot believed that art has fixed principles, but in attempting to justify his aesthetic position in philosophical fashion, reasoning from stated assumptions, he struggles. What will be the compass to guide the artist and keep him on the true path, to choose between the 'good' and the 'better', which may be dangerous? Where the Méthode is content to rely on a simple appeal to good taste, L'Art du violon makes appeal to an artistic conscience, and draws a parallel between the order of sounds which underlies music and the moral order which underlies society, both of which are of divine origin.

Cependant l'art, dont les principes sont immuables, éprouve des changemens que le temps amène dans les formes ...

Mais ici, l'application devient difficile ...

Quel sera donc le guide ...?

Dans notre système musical, il existe un rapport entre les intervalles, un ordre matériel qui n'a point de meilleur juge que l'oreille : l'oreille est la conscience des sons, elle nous avertit de ce qui entretient ou de ce qui trouble cet ordre matériel; c'est ainsi que la conscience, proprement dite, nous éclaire sur ce qui est bien ou mal, selon l'ordre moral; c'est la conscience qui doit être prise pour guide dans tout ce qui est du ressort de l'intelligence et du sentiment : c'est cette voix sécrète, sage conseillère d'une âme immortelle, que l'artiste doit toujours interroger ... le beau devient pour lui le synonyme du bien : l'un, abrégé de l'œuvre divine ... ${ }^{99}$

However, art, though its principles are immutable, does undergo change in its forms over time ...

But here, the application becomes difficult ...

So what guide should the artist follow ...?

In our musical system, there exists a relationship between intervals, a physical order which has no better judge than the ear. Hearing is the awareness of sounds; it

96 Rousselin-Lacombe, 'Piano et pianistes', 125-66.

97 See, for example, Louis Spohr's Autobiography, 113.

98 Louis Spohr's Autobiography, 282-3.

99 Baillot, L'Art du violon, 7. 
lets us know what supports this order or disturbs it. In the same way, conscience enlightens us as to what is good or bad, according to the moral order. Conscience must always be taken as a guide in all that falls within the scope of intelligence and feelings. It is this secret voice, wise counsellor of an immortal soul, to which the artist should always attend ... To the artist, the beautiful becomes synonymous with the good. The first, epitome of the divine work ...

There is something Kantian about this: 'Der gesternte Himmel über mir und das moralische Gesetz in mir' (the starry heavens above me and the moral law within me). From the vantage point of the present day, however, this appeal to morality is no more proof against the march of time than the appeal to taste. It is there in the etymology: morality and moralite have the same origin as the Latin mores (custom), just as the German sittlich (moral) is cognate to Sitten (customs). What is interesting here is the fact that the appeal should be made. The entry on 'taste' in Rousseau's Dictionnaire de Musique asserts that men of good education will generally agree on what constitutes good taste, but acknowledges that there is a problem when they cannot. The only solution he sees is to take a vote. ${ }^{100}$ But an eighteenth-century faith in a sort of limited-franchise democracy is not enough for Baillot in 1834.

The more one reads L'Art du violon, the more one gains the impression that Baillot is not merely outlining a set of personal and institutional convictions, but also defending them. Chief among those convictions is that music is primarily about communicating human feeling. He refers to 'that primal innocence of art which makes us prefer the simple and naïve expression of the heart over brilliance' (ce première innocence de l'art qui nous fait préférer aux qualités brillantes, la simple et naïve expression du Coeur). ${ }^{101}$ The 1834 introduction to Part Two, which is otherwise identical to the 1803 Méthode, returns again to the question of durability. In it, while conceding that there may be changes in style and taste over time, he asserts that the fundamental task of the musician remains the same and so does the language of emotion:

Trois siècles de chefs-d'oeuvre ont déjà prouvé que la philosophie de la musique était fondée sur les principes immuables de la raison et du sentiment ...

Le coeur de l'homme, malgré la mobilité qu'on lui reproche, a dans ses affections une constance, une uniformité, une généalogie de sentimens, si l'on peut s'exprimer ainsi, qui doit rassurer sur la durée des oeuvres du genie ... le coeur répond toujours aux mêmes accens par les mêmes soupirs! ${ }^{102}$

Three centuries of masterpieces have already proven that the philosophy of music was founded on the immutable principles of reason and feeling ...

The heart of man, in spite of the fickleness for which it has been reproached, has in its affections a constancy, a uniformity, a genealogy of feelings, if we can express it thus, which must reassure us as to the durability of works of genius ... the heart always responds to the same accents with the same sighs!

${ }^{100}$ Entry for 'goût', Rousseau, Dictionnaire, 235-6.

${ }^{101}$ Baillot, L'Art du violon, 8.

${ }^{102}$ Baillot, L'Art du violon, 262. It may be useful to note that by the word 'accens', Baillot does not mean the current English usage of 'accent', i.e. the strong start to a note, but the means by which an expression or a character is realized. 
This insistence on the primacy of sensibility is one of the principles which most surely places Baillot in the late eighteenth, early nineteenth centuries.

\section{Historical Consciousness and Historical Irony}

Alongside Baillot's characterizations of what makes a true artist, the section 'Progrès de l'art' also contains an historical description of 'the virtuoso' and 'the nineteenth-century artist':

Le virtuose de nos jours, le plus digne d'admiration est, comme aux temps anciens, celui qui, en sachant d'abord suivre la marche de son siècle dont il est le coryphée, réussit à l'entrainer ensuite par l'impulse de son génie et à lui faire ainsi presser le pas. beau $\ldots{ }^{103}$

.. c'est l'artiste du 19. siècle, c'est l'homme passioné pour tout ce qui est

The virtuoso of our times who is most worthy of admiration is, as in former times, one who by first following the progress of his century of which he is the Choryphaeus, succeeds in leading it by the force of his genius and in hastening its step.

... He is ... the artist of the nineteenth century, a man with a passion for everything which is beautiful ...

It is a curious thing that a nearly identical idea is expressed in Hegel's Rechtsphilosophie (1820): 'The great man of his time is he who expresses the will and the meaning of that time, and then brings it to completion; he acts according to the inner spirit and essence of his time, which he realizes' ${ }^{104}$ Erudite as he was, it seems unlikely that Baillot would have read Hegel, and more likely that this is one of the cases where Baillot's writing resonates with preoccupations of the time, in this case the upsurge of interest in history. Nonetheless, given Baillot's resistance to the cult of virtuosity, he can hardly be said to have hastened the step of the century when it came to playing style. Virtuosity may not have been the last word, but later violinist composers such as Vieuxtemps and Wieniawski certainly embraced it. Spohr and Joachim insisted on a more serious purpose, but their music still makes considerable technical demands, and those demands keep rising in concerto writing through the century. The characterization in Grove of Baillot as 'the last representative of the Classical Paris school of violinists' seems accurate, ${ }^{105}$ that is, until one stops to ask just how much of his approach could be considered classical.

Without wishing to enter into the grand debates about definition, it seems fair to suggest that traits such as modesty, the belief that genius needs restraint and the belief in the importance of good taste could be considered classical, whereas the renewed interest in the past, the emphasis on individual conscience and the assertion of a high moral purpose of music belong rather to a romantic set of beliefs. The primacy of sensibility, the homage to Rousseau (a figure both of and not of the eighteenth century) and the homage to Viotti (whose style Schwartz considers

\footnotetext{
${ }^{103}$ Baillot, L'Art du violon, 9.

${ }^{104}$ Georg Wilhelm Friedrich Hegel, Philosophy of Law, in Jacob Loewenberg, ed, Hegel: Selections (New York, 1929): 461.

${ }^{105}$ Paul David, Manoug Parikian and Michelle Garnier-Panafieu, 'Baillot, Pierre' in Grove Music Online, Oxford Music Online, www.oxfordmusic.com.
} 
'pre-Romantic', 106 and White calls 'classical' ${ }^{107}$ ) are traits which resist easy characterization. The disapproval of empty virtuosity puts Baillot in the company not only of Louis Spohr, but of Robert Schumann. ${ }^{108}$ Discussing prevailing aesthetic directions purely in terms of the classical/romantic divide is too blunt an approach. What we have here is an exaltation of sentiment married with an insistence on virtue. Pleasures were to be pure. ${ }^{109}$ This is an age which grew up on Rousseau's Julie (1761) and subsequently read Chateaubriand's Attala (1801) and de Staël's Delphine (1802). It is the age of Austen's Sense and Sensibility (1811). Perhaps we should call it the Age of Sensibility, and locate it somewhere between eighteenth century rationalism and nineteenth-century romanticism, around 1780-1830. For Madame de Staël, genius should only be bounded by morality and religion. ${ }^{110}$ For Baillot, it must be bounded by taste and tradition as well.

One thing which may be confidently stated is that, in the period between the publication of the Méthode in 1803 and L'Art du violon in 1834, the place of music and the musician were the subject of considerable contest. A fundamental opposition in evidence here is that between the musician as an artist who aims to be faithful to the music itself, and the performer who aims primarily for public success. The tension between these aims is one which has endured. Baillot made it a point of honour to ignore the second, Paganini embraced it, and Spohr was perhaps one of those few who were able to satisfy both imperatives.

\section{Looking Back and Looking Forward}

Baillot lived through the Revolution, the Empire, the Restoration and the July Revolution of 1830 . While his life was buffeted and his outlook undoubtably shaped by these events, it is difficult to determine from his writings just what his politics were. We know from the family letters examined by François-Sappey that he fought in the Revolutionary armies in 1793-94 and declined the intervention of friends which might have enabled him to avoid that duty. ${ }^{111}$ We know from Sauzay's memoirs that Baillot was a member of the National Guard, at least in the 1830s. ${ }^{112}$ However, the former may have as much to do with a sense of patriotic duty as a revolutionary one, and the latter speaks more of a social standing, even an allegiance to the forces of order. What we can say is that, by the time of writing the 1834 treatise, his emphasis on the importance of tradition looks decidedly conservative. There are also passages in $L^{\prime} A r t d u$ violon which suggest a quietist reaction to the Revolutionary years:

\footnotetext{
${ }^{106}$ Schwartz, French Instrumental Music Between the Revolutions, 171.

${ }^{107}$ White, From Vivaldi to Viotti, 348.

${ }^{108}$ Alexander Ringer, 'The Rise of Urban Musical Life' in The Early Romantic Era, ed. Alexander Ringer (Basingstoke, 1990): 8.

${ }^{109}$ The dedication to $L^{\prime} A r t d u$ violon, is characteristic: 'j'ai voulu vous en offrir la dédicace comme un souvenir de nos communs travaux et de nos plaisirs les plus purs' (I wanted to offer you the dedication in memory of our collective labours and our purest of pleasures): Baillot, L'Art du violon, 1.

${ }^{110}$ Germaine De Staël, De l'Allemagne (Paris: Flammarion, 1968; first published 1813): 166.

${ }^{111}$ François-Sappey, 'Pierre Marie François de Sales Baillot (1771-1842) par lui-même', 136-7.

${ }^{112}$ Sauzay and François-Sappey, 'La vie musicale à Paris', 187.
} 
Notre âme, impatiente de briser ses liens, cherche une issue pour s'élancer dans l'infini; - l'imagination, favorisant notre penchant pour le merveilleux, nous prête ses ailes pour nous élever dans des régions inconnues, tant il nous semble beau de quitter la terre ! mais hélas ! il faut bientôt retomber; trahis par notre faiblesse : nous sentons alors la nécessité de nous replier sur nous-mêmes et de chercher la véritable domaine de l'art, non dans le vague, ni dans les choses matérielles ou dans les effets physiques de la nature, mais dans notre propre cœur, dans l'ordre moral et dans le sentiment, cette douce vie de l'âme, cette source intarissable de félicité.

Our soul, eager to break its bonds, seeks an escape into the infinite. The imagination, indulging our yearning for the wondrous, lends us its wings in order to raise us up into unknown realms, so desirable does it seem to leave the earth! But soon, alas, we fall back, betrayed by our weakness, and we feel the need to withdraw into ourselves and to seek the true domain of art not in the nebulous, not in material things or the physical effects of nature, but in our own hearts, in the realm of feeling and emotion, that sweet life of the soul which is the inexhaustible wellspring of happiness. ${ }^{113}$

His resistance to the cults of personality and virtuosity and his veneration of tradition may make Baillot and his ideals appear backward-looking by 1834, but aside from the ambiguous status of the invocation of tradition, there are at least two further ways in which this image needs qualification. The first is an aspect of the comparison between Baillot and Paganini, or Baillot and Lafont, which points to divergent paths to the future: the question of versatility as against specialization.

At the end of Part One of L'Art du violon is a section titled 'Directions diverses que l'on peut donner au talent sur le violon' (The Various Careers to Which Talent on the Violin Can Lead). ${ }^{114}$ In it, Baillot summarizes the different attributes required by the solo violinist, the quartet violinist, the teacher, the orchestral conductor and so on. He notes that only some will be gifted enough 'to unite within [their] personality all the qualities required by these diverse aspects of violinplaying', but he clearly feels that the principles enunciated in the treatise are equally valid for all career paths. From many reports, though best known as a chamber musician, Baillot himself united these gifts. ${ }^{115}$ This was rare and would become rarer still. With the ever-increasing technical demands of the concerto repertoire together with the growth of a historic repertoire, the incentive for the violinist to specialize would increase. In the course of the nineteenth century, the role of orchestral conductor would also become specialized and would cease to be associated with the role of lead violin. While Baillot's principles may have become dated for many of these roles, I suggest that they remained (and remain today) valid for the quartet violinist, particularly in an ensemble which focuses on eighteenth and nineteenth-century repertoire. The intimate gesture, the conscientious study of the musical text, the ability to stand out or fit in as the occasion requires: all these were and remain well suited to chamber music. In this sense, Baillot may be said to be the Coryphaeus of a new kind of artist, the professional chamber musician whose playing has a depth and subtlety which makes many a soloist seem a shallow showman by comparison.

${ }^{113}$ Baillot, L'Art du violon, 6-7. In this case, I have corrected various printing errors, such as 'ame', 'un issue', etc.

${ }^{114}$ Baillot, L'Art du violonIbid, 260-61.

${ }^{115}$ See, for example, Penesco, 'Pierre Baillot et l'école franco-belge de violon', 92. 
The second way in which Baillot pioneered a new tendency, even if one not constantly in vogue, has already been touched upon: he was one of the first, and possibly the first violinist-interpreter. He had a repertoire which stretched from Corelli to works of the present, including his own work. As Spohr records, he played the old and the new equally well. ${ }^{116}$ It is in Baillot's time that 'classical' music was born, in the sense of an historical repertoire including both the old and the new, in which the performer's task was to render the ideas of the composer rather than his/her own. The use of 'classical' in the opening Observations to L'Art du violon is telling. ${ }^{117}$ What is more, we already see with Baillot the beginning of the expectation that the student will first study the established repertoire before tackling modern works. ${ }^{118}$ The ultimate result of this tendency has been the avoidance by many musicians - and by audiences- of contemporary repertoire.

The final way in which Baillot can be said to have led the way, along with his colleagues and the institution which supported them, is in the seriousness which they brought to the business of teaching. It is not so much the noble sentiments of $L^{\prime} A r t d u$ violon which attest to this as the care and effort which has gone into its drafting. The establishment of the Conservatoire decisively raised the status of music teaching. ${ }^{119}$ While this was a collective enterprise, there is no doubt that Baillot played a leading role, both in the institution as a whole and within the trio in whose names the 1803 treatise was written. As noted above, all three contributed to the growth and fame of the French School, but not only did Baillot perform the task of articulating its principles, his students and family came to constitute a veritable dynasty at the Conservatoire. ${ }^{120}$ Furthermore, while all had famous students, and while Kreutzer and Rode contributed invaluable pedagogical works, apart from a few of the early Kreutzer etudes, they are aimed at advanced players. It seems to have been students of Baillot such as Jacques Féréol Mazas (17821-849) and Charles Dancla (18171-907) who contributed to filling out the pedagogical literature with etudes for less advanced players which are still in use today. This is suggestive of a concern for teaching which goes beyond the desire for excellence in performance (Fig. 6).

\section{Conclusion: Productive Rivalries}

$L^{\prime} A r t d u$ violon of Pierre Baillot has a lot to tell us about violin playing of the time and contains much that is still relevant today. Taken together with its precursor, the 1803 Méthode, however, it also has a lot to tell us about the nature of schools of teaching and the nature of change. Baillot and his colleagues were able in a short time to establish a violin school that set the new standard, but there is evidence that the school was soon in need of renewal, as its aesthetic principles were increasingly at odds with the new Romantic style and the growing public taste for virtuoso display. Both catalysts for that renewal came from outside. One was the phenomenon of Paganini, and the other the Belgian violinist Charles de Bériot, who went on to establish a rival school in Brussels.

${ }^{116}$ Louis Spohr's Autobiography, 129.

117 Louis Spohr's Autobiography, 16.

118 'Pour se former un bon style, il faut commencer par se nourrir des auteurs anciens', Baillot, L'Art du violon, 7.

${ }^{119}$ Schwartz, French Instrumental Music Between the Revolutions, 44.

${ }^{120}$ See, for example, Penesco, 'Pierre Baillot et l'école franco-belge de violon', 97. 


\section{L'AUTEUR A SES ELEVES}

\section{MES AMIS}

C'est en cherchant avec vous à pénétrer dans les secrets du violon que je suis parvenu à fixer, dans leur plus grande généralité, les principes de cette nouvelle méthode; il m'est si doux de penser à la part que vous avez prise ainsi à mon ouvrage, que j’ai voulu vous en offrir la dédicace comme un souvenir de nos communs travaux et de nos plaisirs les plus purs.

Puisse ce fidèle ténioin de notre amour pour l'art sublime que nous cultivons, déposer longtemps en faveur du lien d'amitié qui, en m'unissant à vous, mes chèrs élèves, a si puissamment contribué au charme de ma vie

BAILLOT

\section{Fig. 6 Baillot's Dedication to L'Art du violon. ${ }^{121}$}

The Royal Conservatoire of Brussels was established as a state academy along Paris lines under the directorship of Fétis in 1832, although its roots go further back. De Bériot took up his professorship in 1842, having turned down an offer from Paris. Because of the interchange that developed between them, it is customary to treat the violin schools of Paris and Brussels schools as a single 'Franco-Belgian school'. ${ }^{122}$ Penesco goes so far as to describe the Brussels school as a branch of the French school, partly on the basis that de Bériot was a pupil of Baillot. ${ }^{123}$ The research of Schwartz suggests a more complex picture. He insists that de Bériot only sat in on Baillot's classes in 1821 for a few months, declining to enrol because he did not like Baillot's overly scholarly approach. According to Schwartz, de Bériot 'adapted the technical brilliance of Paganini to the elegance and piquancy of the Paris style'. The Franco-Belgian school was thus a fusion of the classical French school and a new approach which was both virtuosic and

121 'The Author to his Pupils. My Friends. It was in trying, with you, to discover the secrets of the violin that I succeeded in establishing, in broad outline, the principles of this new method. I take such pleasure in thinking of the part you have played in this book that I wanted to offer you its dedication in memory of our collective labours and our purest of pleasures. May this faithful reflection of the sublime art we cultivate long serve as testimony to the ties of friendship, which, in joining me to my pupils, have contributed so greatly to the charm of my life'.

122 See, for example, Schwartz, French Instrumental Music Between the Revolutions, 221.

123 Penesco, 'Pierre Baillot et l'école franco-belge de violon', 97-8. 
Romantic in style. ${ }^{124}$ The music of Henri Vieuxtemps, student of de Bériot and teacher of Ysayë, bears this out.

Chassain writes of a French School 'in permanent evolution', but glosses over the stiff resistance mounted by that school to any change in its approach. ${ }^{125}$ This is more obvious in composition, as the cases of Berlioz, Alkan, Ravel and others amply attest. It might therefore be more accurate to describe the progress of the Conservatoire as akin to that of the French polity: proceeding by occasional revolutionary leaps which punctuate periods of deep conservatism. It would be interesting to investigate whether the Paris Conservatoire was more conservative than other institutions which sprang up in emulation of it through the course of the nineteenth century. It may simply be in the nature of such institutions that a dominant approach becomes entrenched and significant change must come from outside. As Baillot himself notes in L'Art du violon, art often loses on one side what it gains on another: ${ }^{126}$ it may be that you cannot have both high general standards and high creativity. Having moved with Viotti from Italy to France, the geographical centre of greatest innovation in violin playing keeps moving east: from Paris to Brussels, to Vienna (Böhm, Dont, Ernst, Hellmesberger, Joachim), via Vieuxtemps and Wieniawski to St Petersburg and via the Hungarian Leopold Auer to New York. De Bériot was able to update the French School precisely because he was not a product of it. Perhaps the further movement followed the same pattern.

\footnotetext{
${ }^{124}$ Boris Schwartz, 'Bériot, Charles-Auguste de', in Grove Music Online, Oxford Music Online, www.oxfordmusic.com.

${ }^{125}$ Chassain, 'Le Conservatoire', 23-4.

126 'le plus souvent, l'art perd d'un côté ce qu'il gagne de l'autre', Baillot, L'Art du Violon, 6.
} 